\title{
Avoiding traditions that undermine laly's potential
}

For years Italy's research council has suffered from scientific direction tainted by political considerations. Changes now in train carry risks that the next generation of Italian scientists will be similarly betrayed.

Ialy's national research council, the Consiglio nazionale delle ricerche (CNR), is undergoing one of the deepest reforms that any European research organization has experienced. A new framework law takes away its role as a grant agency, and dissolves its 14 discredited discipline-based advisory committees. So far so good, given that the advisory panels, afflicted by cronyism, had accumulated uncomfortable levels of power which was not always wielded fairly (see Nature 394, 712; 1998). But there are ways in which the reforms could still stumble.

The purpose of the changes is to improve the quality of research which, while excellent in pockets, has suffered through poor leadership, which often promoted the mediocre, and weak administration. Research minister Luigi Berlinguer would like to see standards equal to that of neighbouring Germany's Max Planck Society (MPS), and evolution to a system with fewer, but bigger, laboratories of greater scientific stature. To that end, the new system puts more power in the hands of the CNR president (currently Lucio Bianco), whose role had hitherto been weakened by the committees. It creates a seven-member decision-making consiglio direttivo, or executive committee, headed by the president and an entirely new scientific committee whose role will be strictly advisory.

Unlike that of the MPS, the executive council is a very political body. Two of its members are selected by the ministry, two by the ministry's own advisory committee, the Assembly of Science and Technology, and two by the CNR president, himself a political appointee. It will have full powers to evaluate institutes, decide on the internal allocation of resources between disciplines and institutes and will have the final say on the appointment of institute directors. It will decide on the new organization of CNR laboratories, whose numbers must be reduced from 300 to 100 . It also has the power to set up new permanent rules governing the establishment, composition and selection of its own scientific advisory structures.

Considering the disastrous effect of political factors on Italy's science over decades, that concentration of power is a cause for deep concern. The role of an independently minded scientific advisory committee becomes all the more important. But the only guideline given by the new law is that half of the scientific committee at the top of the advisory structure must come from within the CNR, half from outside. The worry is that the executive committee might select the scientific committee not just on the basis of scientific qualifications, but also on political criteria. It might turn to the European Commission model, for example, and include representatives of industry and other sections of society. Or it might create a system whereby some scientific committee members are selected by the ministry, as currently, and controversially, happens in France's research council, the CNRS.

Such approaches would be misconceived. The membership of the CNR's scientific advisory committee, and of any subcommittees it sets up, must be restricted to scientists. They should be elected by CNR researchers, just as MPS scientific committee members are elected by MPS scientists. To that end, Bianco would have to withstand resistance from powerful unions which will stand by tradition and demand a vote for all levels of CNR staff, including secretaries and technicians, so diluting the scientific value of the selection.

A fully independent scientific body may go against Italy's grain. But, without such an approach, the CNR will not deserve the financial support it will also require to achieve its goal of outstanding quality. To make the pain of reform worthwhile the CNR will need a budget increase to pay for a much-needed injection of young blood to invigorate its ageing staffing structure. It is, after all, the next generation that must fulfil the purpose of the changes now in progress.

\section{Primakov's advantageous perspective}

\section{Russian science's survival requires the particular attention of the country's new prime minister.}

$\mathrm{O}$ nce again, Russia appears to have stepped back from the brink. Last week's decision by President Boris Yeltsin not to seek a direct confrontation with the lower house of parliament, the Duma, has prompted widespread relief, at home and abroad. Furthermore, his choice of Yevgeny Primakov as the new prime minister, a pragmatist respected for his keen analytical approach to complex problems, offers Russia another chance to put its affairs in order.

Amid his urgent and fundamental problems, Primakov is better placed than most to keep in mind the long term, especially the relevance of his country's dwindling scientific community. The number of working scientists fell from more than 1.1 million in 1989 to 300,000 in 1996. Those who have so far declined either to emigrate or to move into other careers continue to face the indignity of unpaid salaries and vanishing grants. The situation would be even worse if it were not for the substantial research support from foreign agencies (see page 209). But even some of these are losing faith in Russia's prospects.

Primakov could do much to restore this faith by demonstrating a commitment to a continuing active science base, based on high quality research and linked directly to economic and social priorities. A step in this direction would be to increase pressure for reform on the Russian Academy of Sciences (see Nature 387, 533; 1997). Another would be to acknowledge publicly that economic progress requires a healthy system of innovation, which in turn depends heavily on the creative skills of scientists and engineers. Part of the problem facing Russian science is that the political system remains dominated by those with strong links to traditional industries, where interest in research is relatively low. Allowing this sector to continue to control industrial policy would be a recipe for disaster, not only for Russian science but for the rest of the country too. 